IN BRIEF

\section{Séveso row}

When the release of dioxin at Séveso last year was considered at an ecotoxicology workshop held this week under the auspices of NATO's Ecosciences panel, the means of assessing the extent of dioxin poisoning in humans generated heated debate. Dr Guiseppi Reggiani, director of medical research for Hoffmann-La Roche, claimed that chloracne, the disfiguring skin disease observed in some 100 Séveso schoolchildren, was an "obligate sign of dioxin contamination".

Professor Silvio Garattini and Dr Gianni Tognoni of the Mario Negri Institute, Milan, the two main Italian participants, delivered scathing replies. Garattini described Reggiani's statement as "dangerous", and insisted that there was "no acceptable scientific evidence" to support it. $\mathrm{He}$ couldn't accept the implication that the surveillance programme of all residents, and not just children, was a waste of time. Reggiani adhered to his view, and for the future forecast that there would be "no severe health damage to the population at Séveso". The Italians remained unconvinced.

\section{Lead in water: report}

The UK Department of the Environment last week published detailed results of a survey carried out in 1975 on levels of lead in Britain's drinking water. The main findings showed that approximately $4 \%$ of houses in Britain received water containing more than $0.1 \mathrm{mg}$ of lead per litre during the daytime. About $9 \%$ exceeded this level first thing in the morning after water had been standing in pipes during the night. Less than $1 \%$ regularly exceeded $0.3 \mathrm{mg}$ per litre.

The survey found that water fed into the public supply in Britain con- tains minimal levels of lead; but in some areas it has a tendency to dissolve lead in pipes. In a statement, the minister. Mr Peter Shore, said there was a need for more research into the precise causes of lead in water, possible ways of minimising it and the effect it has on health.

The World Health Organisation's upper limit for lead concentrations in water is $0.3 \mathrm{mg}$ per litre.

\section{Oil spill policy}

The government set out its policy for coping with oil spills at sea last week. Wherever possible, it states, oil spills should be left to degrade naturally; but where there is a serious pollution threat chemical oil dispersants should be used. Provision will be made to cope with spills of 16,000 tonnes per day offshore and 1,000 tonnes per day onshore and in inshore waters.
For the last ten years we have been bombarded with propaganda about impending world overpopulation. Even in countries like Britain, where the increase is relatively slow, it has been pointed out that if this continues we too will have 'standing room only' within a few hundred years. Though this will not happen, things could become more uncomfortable. But planning even for shorter periods such as the next twenty or thirty years could be much more effective if we had reasonably accurate population forecasts. Our Office of Population Censuses and Surveys (OPSC) makes a valiant effort, but their results have, so far, not been very encouraging.

During the first twenty years after the 1939-45 War, the birth rate was unexpectedly high, particularly among the middle classes, when Britain's 'top people' proudly announced in the Times newspaper that they had produced "Jemima, a sister for Jason, Emma, Susan, Giles, Jeremy and Natasha". The country had a minor population explosion. Then during the last ten years the forecasts have been bedevilled by the unexpected and catastrophic drop in the birthrate, so that Britain's population is actually falling.

The effects of this recent change are well illustrated in the recent OPCS Monitor giving population projections for England and Wales up to the vear 2010. In 1970 there were about 800,000 live births; the estimate for the total population for 2010 was 62 million. By 1976 births had fallen by some 200,000 , and based on this figure the forecast

for 2010 was only 51 million. It will now available, very small changes in the birthrate have substantial effects on further population projections. Every baby not born this year will subtract

\section{People projections}

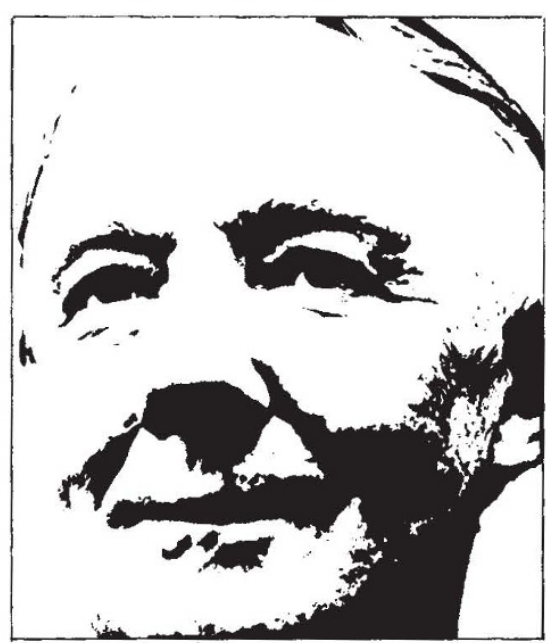

\section{KENNETH MELLANBY}

something like 50 individuals from the figure for 2010.

In less developed countries, population increase results mainly from the falling death rate. This is less important in Britain, where people mostly live longer, but the OPCS suggest that over the next 40 years there may be a further fall of $10 \%$ in the death rate, mainly affecting the young (infant and neonatal mortality) and the aged. This would produce a larger number of men and women over 70, and impose an increasing burden on health services and pension funds. But will this forecast be any more accurate than that about births? We know that rats underfed in the their youth live much longer than their littermates who receive a generous diet. Are overfed babies, toddlers, teenagers and adults likely to survive as well as previous, more austerely raised, generations?

When Britain's population was growing rapidly, in the late 1960s and early 1970 s, there were many calls to our various governments to implement population policies to produce, as soon as possible, stability ('zero population growth'). Both Labour and Conservative governments made sympathetic noises, they set up commissions and committees, and they did absolutely nothing.

Britain's politicians must now be kicking themselves for not being able to take the credit for the greatly reduced birthrate. If only in 1969 or 1972 they had promulgated a definite policy-any sort of policy-and had appeared to act vigorously, they could now point out that although they had not stimulated economic growth, built more houses or cured unemployment. their population policy had been completely successful. However, the cynic may say that, had government encouraged population stability, we would all have responded by breeding like rabbits. 